\title{
Study on the Psychological Dynamics of Single parent Students in School Life
}

\author{
Cui Liu \\ Sichuan Information Technology College, Guangyuan, 628017, China. \\ 182393203@qq.com
}

\begin{abstract}
Due to various reasons, the number of single parent students in higher vocational colleges in our country is increasing, and the school did not pay attention to their mental health. In this paper, we investigated a total of 496 students in Sichuan Information Technology College, including 114 single parent students and 382 students with perfect family. Through the comparative analysis of their psychological state, found that the psychological problems of single parent students, and then puts forward the work that the school should do to educate these students.
\end{abstract}

Keywords: Single parent student; higher vocational college; psychological state; education method.

\section{Background}

With the development of the society, our country has made great changes with the opinions about marriage and family. Since 2003, the divorce rate in China continuous increase for 12 years ${ }^{[1]}$, plus some children out of wedlock, widowed, etc., lead to the group of single-parent students is becoming bigger and bigger. Many single parent students lack of the warmth of family and family education in the process of growth, lead to the emergence of weariness, truancy, addicted to online games and other bad behavior. The higher vocational colleges have become the "concentration camp" of this kind of student because of the low entry threshold.

These students often show a weak sense of interpersonal communication, eccentricity, low self-esteem after the entrance ${ }^{[2]}$. Research on their psychological dynamics can help them change their values, it is good for their work and life after the school life.

\section{Psychological Status of Single-parent Students in Higher Vocational Colleges}

Table 1. Compare the psychological state of the students with the perfect family and the single parent family

\begin{tabular}{|c|c|c|c|c|c|c|c|c|}
\hline \multirow{2}{*}{ Survey questions } & \multicolumn{3}{|c|}{382 students with perfect } & \multicolumn{3}{c|}{114 students with single parent } \\
\cline { 2 - 9 } family & yes & ratio & no & ratio & yes & ratio & no & ratio \\
\hline $\begin{array}{c}\text { Have a clear learning goals or } \\
\text { not }\end{array}$ & 181 & $47.38 \%$ & 201 & $52.62 \%$ & 34 & $29.82 \%$ & 80 & $70.18 \%$ \\
\hline $\begin{array}{c}\text { Insist study is useful for future } \\
\text { development or not }\end{array}$ & 245 & $64.14 \%$ & 137 & $35.86 \%$ & 46 & $40.35 \%$ & 68 & $59.65 \%$ \\
\hline $\begin{array}{c}\text { Have a complete career } \\
\text { planning or not }\end{array}$ & 221 & $57.85 \%$ & 161 & $42.15 \%$ & 9 & $7.89 \%$ & 105 & $92.11 \%$ \\
\hline $\begin{array}{c}\text { Insist career planning is useful } \\
\text { for future development or not }\end{array}$ & 241 & $63.09 \%$ & 141 & $36.91 \%$ & 13 & $11.40 \%$ & 101 & $88.60 \%$ \\
\hline Feel fear for marriage or not & 43 & $11.26 \%$ & 339 & $88.74 \%$ & 82 & $71.93 \%$ & 32 & $28.07 \%$ \\
\hline $\begin{array}{c}\text { Accept the other party broke } \\
\text { up or not }\end{array}$ & 344 & $90.05 \%$ & 38 & $9.95 \%$ & 19 & $16.67 \%$ & 95 & $83.33 \%$ \\
\hline $\begin{array}{c}\text { Have a duty to bear social } \\
\text { responsibility or not }\end{array}$ & 311 & $81.41 \%$ & 71 & $18.59 \%$ & 59 & $51.75 \%$ & 55 & $48.25 \%$ \\
\hline Feel social injustice or not & 84 & $21.99 \%$ & 298 & $78.01 \%$ & 91 & $79.82 \%$ & 23 & $20.18 \%$ \\
\hline
\end{tabular}

To December 2015, there are more than 10 million students in higher vocational college in China, which the number of single-parent students accounted for about 20\%. This paper takes Sichuan 
Information Technology College of 496 students as the object of investigation, in which 114 single parent students. The survey results are shown in Table 1.

Study the data on the Table 1, we found that there are some problems in the psychological state of single parent families.

\subsection{Learning Goals are not Clear.}

Students in school learning, learning is the most important task, there is a direct relationship between learning achievement and learning goal. Clear learning goals can urge students to study hard in order to achieve a goal. According to the survey results of vocational students' learning goals, $43.78 \%$ and $64.14 \%$ of students with a perfect family have a clear learning goal and insist study is useful for future development, and the proportion of students with single-parent family is $29.82 \%$ and $40.35 \%$.

This shows that due to the employment pressure increasing in recent years, the higher vocational students' learning enthusiasm and motivation is declining, and the performance is more obvious in the single parent students.

\subsection{Career Planning is not Complete.}

A complete career planning can make people to refuse the temptation of short-term, and unswervingly move forward towards their goals, and ultimately achieve success. $92.11 \%$ of single parent families do not have a complete career planning, $88 \%$ of that think career planning is not useful for the future development. These two data are both higher than students with perfect family. Family sound students may have an understanding of the situation in the industry under the guidance of parents and single parents students rarely get their parents' guidance in this field, or the parents want to lead but the child to rebel or do not pay attention to that.

\subsection{Marriage Concept has a Deviation.}

Some students from single parent family because of the lack of parental care since childhood, do not understand how to get along with the opposite sex. Part of the students experienced the relationship breakdown of their parents and feel fear on marriage and family.

$71.93 \%$ of single parent students said it would not be easy to enter the marriage but $88.74 \%$ of other students said that they willing to get marry. In addition, $83.33 \%$ of single parent students can't stand each other's betrayal. It shows that the students of single parent families are more cautious about love and marriage and the loyalty is more value.

\subsection{Lack of Social Responsibility.}

The sense of social responsibility refers to the specific society in which people live, each individual must bear some care obligations to other groups or individuals.

Nearly half of the single parent students think that there is no obligation to assume social responsibility, this ratio is more than 2.5 times of the students with perfect family. There are more than three quarters in single parent students think social is injustice, this ratio in the students with perfect family only $1 / 5$.

Through visits to these students' counselors, we found that single parent students are not easy to trust and rely on the people around them. Appearance may be very strong, but the heart is very fragile, very concerned about other people's views on their own. In general, they like to use their own way to solve the problem, but when things get done, they trend to find excuses for their own reasons.

\section{Single Parent Families of High Vocational College Students the Causes of Psychological Problems}

Any problem is not caused by a single cause. This paper intends to analyze the reasons for the psychological problems of single parent students in higher vocational colleges from three aspects: the students themselves, the family environment and school education.

\subsection{Students Themselves: Personal Cognition and the Development of Personality Defects.}

As previously noted, single parent students in higher vocational colleges are relatively poor in their own knowledge. To a certain extent, decided that they are relatively weak in the ability of self 
recognition and value judgment and choice, in the analysis of things and problems tend to be more emotional and lack of rational thinking.

In these students, there is a part of the fact still know how to do is correct, but because of their own experience and rebellion, the correct concept can not be the upper hand, so often produce some bad behaviors. These bad behavior will bring convenience to life and even cheerful mood which is provide the internal power for these acts.

\subsection{Family Environment: Education Function is Weak and has a Negative Impact.}

According to the literature, there are three types of education in single parent families, which are violent, dote and laissez faire. It is certain that these three kinds of educational methods are not conducive to the growth of single parent students.

Children who grow up in violent education are prone to moral and cognitive deficiencies and indifference to the outside world because subjected to mental and physical abuse for a long time. The doting type of education is often exist in two cases, one is grandparents of children obey in every way to ease the pain in the hearts of children, other one is the parents feel affection owe children as far as possible to meet their requirements. This will cause the child can not withstand setbacks, the performance of self willed, can not be criticized, the state of mind is extremely fragile. Children growth under the laissez faire education due to the lack of timely guidance and correction in the growth process, it is easy to form a dual personality, is not conducive to the formation and development of independent consciousness and ability.

\subsection{School Education: Insufficient Attention and Lack of Methods.}

At present, higher vocational education in our country always pay attention to the cultivation of skills and ignore the cultivation of humanistic quality. What is more, some teachers simply the problem of single parent students can be attributed to the ideological and moral problems, do not to a profound analysis of the problems hidden reasons, just plain rude unwarranted accusations. For the students from single parent families already fragile psychological amounts to "worse". In addition, some teachers believe that education is a family of students, the school is only responsible for teaching survival skills.

\section{Thoughts on the Education Method of Single Parent Families in Higher Vocational Colleges}

According to the results of the survey and the analysis of the previous paper, the paper puts forward the following suggestions on the psychological health of single parent students in Vocational Schools:

Table 2. Suggestions on the education method of single parent students in higher vocational colleges

\begin{tabular}{|c|c|c|}
\hline problem & phenomenon & Solution method \\
\hline $\begin{array}{l}\text { Schools do not attach } \\
\text { importance to the } \\
\text { psychological problems } \\
\text { of students }\end{array}$ & $\begin{array}{l}\text { Attach importance to skill } \\
\text { education, ignore } \\
\text { accomplishment }\end{array}$ & $\begin{array}{l}\text { Increase the proportion of humanities } \\
\text { courses }\end{array}$ \\
\hline $\begin{array}{l}\text { Teachers lack the correct } \\
\text { educational } \\
\text { consciousness. }\end{array}$ & $\begin{array}{l}\text { Teachers believe that } \\
\text { education is the responsibility } \\
\text { of the family, the school is } \\
\text { only teaching skills }\end{array}$ & $\begin{array}{l}\text { Train the teacher and turn around the } \\
\text { wrong ideas }\end{array}$ \\
\hline $\begin{array}{l}\text { Teachers lack the correct } \\
\text { educational method }\end{array}$ & $\begin{array}{l}\text { Teachers do not deep analysis } \\
\text { of the problem, just a simple } \\
\text { scolding }\end{array}$ & $\begin{array}{l}\text { To investigate the background of the } \\
\text { students, the implementation of } \\
\text { personalized education; Create a good } \\
\text { collective atmosphere; Strengthen ties } \\
\text { with parents }\end{array}$ \\
\hline
\end{tabular}

According to the results of the survey and the analysis of the previous paper, the following suggestions are put forward on the way of school education for the mental health of single parent students in higher vocational colleges. For details see attached Table 2. 
Although the causes of the psychological problems of single parent students in higher vocational colleges are various, but from the perspective of school education is mainly the above three reasons.

Schools do not attach importance to the psychological problems of students. Higher vocational colleges have always put teaching student's skills in the first place in China. The school does not care about the students' humanistic quality, so did not give the correct guidance in a timely manner. School could increase the proportion of humanities courses to solve this problem. Teachers lack the correct educational consciousness. Usually the teacher thinks the school only teaches students skills is enough, as for ideological education should be the responsibility of the family. So they often turn a blind eye to the students' psychological problems. School should strengthen the education of teachers on the matter. Teachers lack the correct educational method. Because the teacher simply does not have the correct sense of education, so they cannot have the right educational methods. They just scold and punish them when they make mistakes, and never pay attention to the deep reasons, not to mention the understanding inner thoughts of each single parent students. Single parent students will be more morose and extreme in this case, because psychological problems can not be found in time and have the correct guidance. Face this situation, teachers should strengthen the education of single parent students from many aspects, suggestions are the followings:

To investigate the background of the students, the implementation of personalized education. Understanding the background and experience of single parent students is good for understanding their psychological activities. Create a good collective atmosphere. As we all know, the impact of the collective environment on people is enormous, they can be driven by a positive and uplifting collective environment, to eliminate the negative part of their minds. Strengthen ties with parents. As a result of the psychological problems of single parent students there are schools and families, solving this problem also needs the joint efforts and cooperation of schools and families. So teachers and parents should always contact, to help single parent students overcome psychological barriers.

\section{Conclusion}

The change of the social situation in our country and the expansion of higher vocational colleges has caused more and more single parent students in higher vocational colleges. According to the survey, it is found that there are some problems in their psychology. These problems are caused by many factors such as single parent students themselves, family environment, and school education and so on. In order to solve the psychological problems of single parent students in higher vocational colleges, the school as a student's main activity place should take the main responsibility, to provide a good education for single parent students.

\section{References}

[1] Li Hongxiang. The characteristics of the increasing divorce rate in China and its legal countermeasure [J]. Social science front, 2015(6).

[2] Wu Hongming. Special family student groups deserve attention [J]. Chinese Journal of Education, 2015(10):108-108. 